\title{
Pharmacognostical and phytochemical analysis of Lepidium sativum L. seeds
}

\author{
Rizwan Ahmad ${ }^{1,2},{ }^{*}$ Mohd Mujeeb ${ }^{3}$, Firoz Anwar ${ }^{4,5}$, Asif Husain ${ }^{6}$, Aftab Ahmad7, Saurabh sharma ${ }^{1}$ \\ ${ }^{1}$ Department of Pharmacy, Faculty of Pharmacy, Vivek College of Technical Education, Bijnor (Uttarpradesh), India \\ ${ }^{2}$ Uttarakhand Technical University, Dehradun (Uttarakhand), India \\ ${ }^{3}$ Department of Pharmacognosy \& Phytochemistry, Faculty of Pharmacy, Jamia Hamdard, New Delhi-110062, India \\ ${ }^{4}$ Department of Pharmacology, Siddharth institute of Pharmacy, Dehradun- Uttarakhand \\ ${ }^{5}$ Department of Biochemistry, Faculty of Science, King Abdulaziz University, Jeddah-21589, Kingdom of Saudi Arabia \\ ${ }^{6}$ Department of Pharmaceutical Chemistry, Faculty of Pharmacy, Jamia Hamdard, New Delhi-110062, India \\ ${ }^{7}$ Health Information Technology Department, Jeddah Community College, King Abdulaziz University, P.O. Box- 80283, Jeddah- \\ 21589, Kingdom of Saudi Arabia
}

\begin{abstract}
Objective of the present study was to carry out the physicochemical and phytochemicals standardization of Lepidium sativum L seeds to establish the standard pharmacognostical parameters of this valuable medicinal plant. Many standardization parameters of Lepidium sativum were analyzed. Standard method was adopted for the preliminary phytochemicals screening. Analysis of pesticides residues, aflatoxin \& heavy metals were also performed. The sections of seeds were prepared for quantitative microscopic parameters. The air dried powdered plant material was subjected for determination of physicochemical standardizations like ash value, Extractive value and fluorescence nature of the powder drug using light of short and long wavelength of $254 \mathrm{~nm}$ and $366 \mathrm{~nm}$ respectively. Phytochemical screening was performed for the identification of phytoconstituents in the plant which was helpful in the development of analytical profile. The morphological and microscopic examinations of drug were revealed the presence of endosperm cell which are polygonal in shape and contain alerone grains and oil droplet, cell of testa, yellow colouring matter and starch grains. Preliminary phytochemical screening showed the presence of carbohydrates, phenolic compounds, flavonoids, alkaloids, proteins, saponins and lipids in the drug extract and flourescence nature of drug was confirmed by fluorescence analysis in different solvent. Concentrations of heavy metals, ash value and extractive value were determined and found within acceptable Pharmacopoeial limits. Pesticides residues and aflatoxins were also determined but not detected in the tested samples. The physicochemical and phytochemical standards which are outcome of this research may be utilized as substantial data for identification and standardization of L. sativum seed.
\end{abstract}

Key Words: Garden cress, brassicaceae, aflatoxins, pesticides residue, extractive value, heavy metal.

\section{INTRODUCTION}

Lepidium sativum Linn (Brassicaceae) is an annual herb locally known as halon in india but commonly known as Garden cress. Lepidium sativum is a polymorphous species and its centre of origin is Eritre and Ethiopia. Halon is a fast-growing edible plant. Seeds, roots and leaves of Gardencress are of economic importance; but, the crop is mainly cultivated for seeds. It is a medicinal important herb in India (Paolo Scartezzini, and Ester Speroni, 2004) it is an erect, glabrous, annual, herbaceous plant growing upto $15-45 \mathrm{~cm}$ in height. It has small white flowers in long racemes. The pods of halon are obovate, rotundate, elliptic, notched at apex emarginated, and winged. It can be grown at all elevations, throughout the year, but the best herb is obtained in the winter season. The leaves of the plant are used in salads, cooked with other vegetables and used to garnish food. Leaves are stimulant and diuretic (Maghrani et al., 2005; Wright et al., 2007). Halon seeds are brownish red in colour and oval in shape (AlYahya et al., 1994). Morphologically, L. sativum seeds resemble that of seed oil with the dicotyledonous endosperm approximately to $82-85 \%$ of the seed content, the seed coat content $12-18 \%$ and the embryo for $2-4 \%$ of

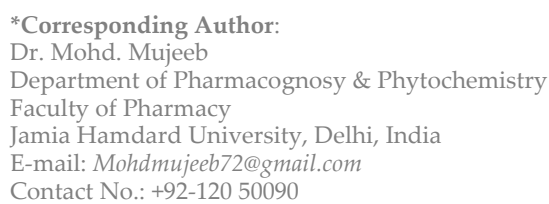

the seeds, respectively. Seeds contain $27 \%$ of protein, 14 $26 \%$ of lipids, $35-54 \%$ of carbohydrates and $8 \%$ of crude fibre (Mathews et al., 1993). The carbohydrates of the $L$. sativum seeds comprise of $90.0 \%$ non-starch polysaccharides and $10 \%$ of starch. The seed bran has high dietary fibre content and also it has high water holding capacity. Seed bran can be used as a rich source of dietary fibre (Gokavi et al., 2004). L. sativum seed contains 20-25\% semidrying yellowish oil and the mostly fatty acid in it is alpha linolenic acid (32-35\%). Garden cress oil has a balanced amount polyunsaturated fatty acids (46.8\%) and monounsaturated fatty acids $(37.6 \%)$ and also contains natural antioxidants viz., tocopherols and carotenoids which protect the oil from rancidity. Seven imidazole alkaloids, lepidine B, C, D, E, and F and two new monomeric alkaloids semilepidinoside $\mathrm{A}$ and $\mathrm{B}$, sinapic acid and sinapin were reported in seeds of L. sativum (Maier et al., 1998). Benzyl isothiocyanate and benzyl cyanide were reported in colourless volatile oil but $\alpha$ tocopherol and $\beta$-sitosterol were reported in the unsaponifiable matter of halon seeds (Lee et al., 2004). A detailed study on phytochemical properties of halon seed oil has been reported. L. sativum seeds have been used in traditional medicine since old times in India (McConnell et al., 2007). The roots of halon are acrid and bitter which are useful in treatment of secondary syphilis and used as a condiment (Welbourne, 1979). The aqueous extract of $L$. sativum seeds promoted hypoglycaemic activity both in normal and diabetic rats without interfering insulin secretion (Eddouks et al., 2005). Standardization of $L$. 
sativum seeds have not been reported so far. In the present investigation, quality standards of $L$. sativum were developed to establish quality and purity of the drug.

\section{MATERIALS AND METHODS}

\section{Procurement of plant material}

Lepidium sativum $\mathrm{L}$ seeds were collected from herbal gardenof Hamdard University campus, New Delhi, India, (July -2011) and samples were identified by taxonomist. The voucher specimen was deposited in Pharmacognosy and Photochemistry research laboratory, Vivek College of Technical Education, Bijnor for further reference (voucher no. NISCAIR/RHMD/Consult/-2011-12/1781/81).

\section{Macroscopical and microscopical evaluation}

The plant material of halon was subjected to macroscopical and microscopical evaluation. The seeds of L. sativum were monitor carefully and preliminary observations were recorded. The seeds were powdered with the help of grinder and stained with different staining reagent to ascertain the presence of particular type of microscopical characters.

\section{Physicochemical standardization Determination of extractive value}

It is the amount of soluble component extracted with different solvents from a given amount of crude drugs (Harborne, 1999).

\section{Cold Extraction}

The dried drugs powder $(10 \mathrm{gm})$ was macerated with solvent (Petroleum ether, chloroform, methanol and water) of volume $100 \mathrm{~mL}$ in a round bottom flask for 24 hours, shaking continuously for six hours and allowing standing for 24 hours. It is filtered rapidly and evaporates the filtrate to dryness in a flat bottom dish and dried at $105^{\circ} \mathrm{C}$, to constant weight and calculated percentage yield.

\section{Hot Extraction}

The powder material of the halon drug (10gm) was packed in a Soxhlet assembly separately for each solvent like petroleum ether, chloroform, methanol and water. Extract of halon was evaporated to dryness and constant extractive value was calculated.

\section{Successive Extraction}

Successive extraction of dried powdered material of halon drug $(10 \mathrm{gm})$ was done in a Soxhlet assembly with different solvents like petroleum ether, chloroform and methanol. The extracts of halon were evaporated to dryness and their constant extractive values were recorded.

\section{Determination of ash values}

Ash value is a physiochemical parameter of drugs which is helpful in detection of adulteration as well as establishes the quality and purity of the drug.

\section{Determination of total ash values}

Ignition of Lepidium sativum seed material yields total ash which containing physiological and non-physiological ash. The crude halon drug was incinerated in a crucible at a temperature not exceeding $450^{\circ} \mathrm{C}$ until free from carbon. It was then cooled and weighed to get the total ash content value.
Determination of acid insoluble ash values

Acid insoluble ash represents siliceous earth and sand. Ash is boiled with $25 \mathrm{~mL}$ dilute hydrochloric acid (6N) for five minutes. The insoluble content collected on an ash less filter paper, then washed with hot water and ignited at a temperature not exceeding $450^{\circ} \mathrm{C}$ to a constant weight.

\section{Determination of water-soluble ash values}

Ash was dissolved in distilled water and the insoluble portion collected on an ash less filter paper and ignited at $450^{\circ} \mathrm{C}$ to constant weight. By subtracting the weight of insoluble portion from that of the ash, the weight of soluble part of ash was estimated.

\section{Florescence analysis}

The fluorescence character of the halon seed powders was studied in UV and daylight light (366 and $255 \mathrm{~nm}$ ) by treatment with different reagents like sodium hydroxide, picric acid, hydrochloric acid, nitric acid, iodine acetic acid and ferric chloride etc. (Chase, 1949; Kokoshi, 1958).

\section{Phytochemical screening}

The petroleum ether, chloroform, methanolic and aqueous extract of the halon were subjected to preliminary phytochemical investigation for the detection of secondary metabolites (Mukherjee, 2002). The phytoscreening was performed for alkaloids, carbohydrates, protein, saponins, phenolic compounds, flavonoids mucilage, resins and lipids or fats etc.

\section{Heavy metal residues}

Determination of heavy metals (cadmium, lead, arsenic and mercury) analysis was carried out in the extracts of $L$. sativum on Atomic Absorption Spectrophotometer according to the American Organization of Analytical Chemists (AOAC) (Anonymous, 2002; Anonymous, 2003).

\section{Pesticide residues}

Pesticides (organophosphates organochlorines and pyrethroids) residues in the halon extracts were carried out by GC-MS as per the guideline of American Organization of Analytical Chemists (AOAC) (Anonymous, 2002; Anonymous, 2003).

\section{Aflatoxin analysis}

Aflatoxins were analyses in L. sativum extracts by HPLC method as mention in American Organization of Analytical Chemists (AOAC) (Anonymous, 2002; Anonymous, 2003).

\section{RESULTS AND DISCUSSION}

The macroscopical study of the $L$ sativum $L$ seeds was done. The seeds were pale brown to brown red in colour, 2-3 $\mathrm{mm}$ in size, oval in shape with smooth surface \& characteristic odour (table 1). The microscopic examination of powdered material was performed to detect and established various identifying microscopic characters which will be helpful in authentication of the alternative drug supplied in the form of dried powder. The photomicrographs of the identifying features of the plant material are shown in (figure 1-3). The cells of endosperm were seen and the cells are polygonal in shape and contain alerone grains and oil droplet. The cells of testa are longitudinal, elongated and they are closely packed and contain yellow colouring matter. The starch grains were also present which are oval and rounded in shape.The various physiochemical parameter like ash values, 
Table 1: Macroscopical characters of L. Sativum.

\begin{tabular}{ccc}
\hline Sr. No & $\begin{array}{c}\text { Macroscopic } \\
\text { Characters }\end{array}$ & Observation \\
\hline 1 & External Colour & Pale brown to Brownish red \\
2 & Size & $2-3 \mathrm{~mm}$ \\
3 & Shape & Oval \\
4 & Surface & Smooth \\
5 & Odour & Characteristic \\
6 & Taste & Bitter \\
\hline
\end{tabular}

Table 2: Summary of results of physicochemical evaluation of drug $(n=3)$.

\begin{tabular}{|c|c|c|}
\hline \multicolumn{2}{|r|}{ Parameters } & $\begin{array}{l}\text { Lepidium sativum } \\
\% \mathrm{w} / \mathrm{w}\left(\text { mean } \pm \mathrm{SD}^{*}\right)\end{array}$ \\
\hline \multicolumn{2}{|c|}{ Moisture content } & 5.8 \\
\hline \multirow{3}{*}{ Ash values } & Total Ash & 1.57 \\
\hline & Acid insoluble Ash & 0.74 \\
\hline & Water soluble Ash & 0.83 \\
\hline \multirow{5}{*}{$\begin{array}{l}\text { Successive } \\
\text { extraction }\end{array}$} & Petroleum ether & 2.05 \\
\hline & Chloroform & 2.67 \\
\hline & Methanol & 9.09 \\
\hline & Water: alcohol (50:50) & 4.94 \\
\hline & Water & 0.294 \\
\hline \multirow{6}{*}{$\begin{array}{l}\text { Detection of } \\
\text { contaminants }\end{array}$} & Heavy Cadmium $(\mathrm{Cd})$ & $0.24 \pm 0.02$ \\
\hline & metals** Lead $(\mathrm{Pb})$ & $0.42 \pm 0.14$ \\
\hline & Arsenic (As) & $0.48 \pm 0.06$ \\
\hline & Mercury (Hg) & $0.38 \pm 0.06$ \\
\hline & Aflatoxins (B1,B2, G1 and G2) by HPLC & $\begin{array}{l}\text { Aflatoxins, B1, B2, G1 and G2 were analysed by using HPLC } \\
\text { method, which were found absent in all samples }\end{array}$ \\
\hline & $\begin{array}{l}\text { Pesticides ( } 30 \text { pesticides were checked) by } \\
\text { GC-MS }\end{array}$ & $\begin{array}{l}\text { The } 30 \text { pesticides were analyzed by using GC-MS method, } \\
\text { which were found absent in all samples }\end{array}$ \\
\hline
\end{tabular}

Table 3: Effect of different chemical reagents on the fluorescence behaviour of crude drug powder.

\begin{tabular}{clccc}
\hline Sr. & \multicolumn{1}{c}{ Treatment } & Day light & UV light & UV light \\
No. & & 254 nm & 366 nm \\
\hline 1 & Powder as such & Brownish red & Brownish red & Brown \\
2 & Powder treated with distilled water & Brownish red & Dark brown & Dark brown \\
3 & Powder treated with 1N NaOH in water & Brownish red & Brownish red & Brown \\
5 & Powder treated with $\mathrm{HNO}_{3}$ & Light brown & Dark green & Dark violet \\
6 & Powder treated with $\mathrm{H}_{2} \mathrm{SO}_{4}$ & Green & Black & Blue \\
7 & Powder treated with iodine & Green & Blue & Dark brown \\
8 & Powder treated with conc. HCl & Dark green & Radish brown & Greenish black \\
9 & Powder treated with ammonia & Light green & Dark green & Greenish brown \\
10 & Powder treated with ferric chloride & Green & Radish black & Greenish brown \\
11 & Powder treated with Iodine & Brown & Blue \\
12 & Powder treated with Glacial acetic acid & Yellow & Dark yellow & Yellow \\
13 & Powder treated with Picric acid & Dark yellow & Yellow & Dark yellow \\
14 & Powder treated with Petroleum ether & Dark green & Pale yellow & Dark Brown \\
15 & Powder treated with Chloroform & Dark green & Dark brown & Dark gr \\
\hline
\end{tabular}

Table 4: Results of Phytochemical screening.

\begin{tabular}{lcccc}
\hline \multicolumn{4}{c}{ Constituents } & \multicolumn{5}{c}{ Extracts } \\
\cline { 2 - 5 } & $\begin{array}{c}\text { Petroleum } \\
\text { ether }\end{array}$ & $\begin{array}{c}\text { Chloro- } \\
\text { form }\end{array}$ & $\begin{array}{c}\text { Alcoholic } \\
\text { Aqueous }\end{array}$ \\
\hline Alkaloids & - & + & + & + \\
Carbohydrates & - & - & - & + \\
Phenolic compounds & - & + & + & - \\
Flavonoid & - & + & + & + \\
Proteins and amino- & - & - & + & + \\
acids & - & - & + & + \\
Saponins & - & - & + & - \\
Mucilage & + & + & + & - \\
Resins & + & - & - & - \\
Lipids / Fats & & & &
\end{tabular}

Table 5: Determination of heavy metal residues.

\begin{tabular}{ccc}
\hline $\begin{array}{c}\text { Sr. } \\
\text { No }\end{array}$ & Heavy Metals & Concentration \\
\hline 1 & Cadmium $(\mathrm{Cd})$ & $0.24 \pm 0.02$ \\
2 & Lead $(\mathrm{Pb})$ & $0.42 \pm 0.14$ \\
3 & Arsenic $(\mathrm{As})$ & $0.48 \pm 0.06$ \\
4 & Mercury $(\mathrm{Hg})$ & $0.38 \pm 0.06$ \\
\hline
\end{tabular}


Table 6: Determination of pesticide residue.

\begin{tabular}{|c|c|c|c|c|}
\hline Sr. No & Pesticide & Test method & Results & MDL \\
\hline 1 & $\alpha-\mathrm{BHC}$ & AOAC $970.52 / E P A 525.5$ & Not detected & $0.01 \mathrm{mg} / \mathrm{kg}$ \\
\hline 2 & $\beta-\mathrm{BHC}$ & AOAC $970.52 / E P A 525.5$ & Not detected & $0.01 \mathrm{mg} / \mathrm{kg}$ \\
\hline 3 & $\gamma$-BHC(Lindanee) & AOAC $970.52 / E P A 525.5$ & Not detected & $0.01 \mathrm{mg} / \mathrm{kg}$ \\
\hline 4 & $\delta-\mathrm{BHC}$ & AOAC $970.52 / E P A 525.5$ & Not detected & $0.01 \mathrm{mg} / \mathrm{kg}$ \\
\hline 5 & Heptachlor & AOAC $970.52 / E P A 525.5$ & Not detected & $0.01 \mathrm{mg} / \mathrm{kg}$ \\
\hline 6 & Heptachlor_Epoxide & AOAC $970.52 / E P A 525.5$ & Not detected & $0.01 \mathrm{mg} / \mathrm{kg}$ \\
\hline 7 & $\alpha$-Chlordane & AOAC $970.52 / E P A 525.5$ & Not detected & $0.01 \mathrm{mg} / \mathrm{kg}$ \\
\hline 8 & $\alpha$-Endoulfan & AOAC $970.52 / E P A 525.5$ & Not detected & $0.01 \mathrm{mg} / \mathrm{kg}$ \\
\hline 9 & $\beta$-Chlordane & AOAC $970.52 / E P A 525.5$ & Not detected & $0.01 \mathrm{mg} / \mathrm{kg}$ \\
\hline 10 & Endrin & AOAC $970.52 / E P A 525.5$ & Not detected & $0.01 \mathrm{mg} / \mathrm{kg}$ \\
\hline 11 & Total DDE & AOAC $970.52 / E P A 525.5$ & Not detected & $0.01 \mathrm{mg} / \mathrm{kg}$ \\
\hline 12 & Total DDD & AOAC $970.52 / \mathrm{EPA} 525.5$ & Not detected & $0.01 \mathrm{mg} / \mathrm{kg}$ \\
\hline 13 & Total DDT & AOAC $970.52 / E P A 525.5$ & Not detected & $0.01 \mathrm{mg} / \mathrm{kg}$ \\
\hline 14 & $\beta$-Endoulfan & AOAC $970.52 / E P A 525.5$ & Not detected & $0.01 \mathrm{mg} / \mathrm{kg}$ \\
\hline 15 & Endrin_Aldehyde & AOAC $970.52 / E P A 525.5$ & Not detected & $0.01 \mathrm{mg} / \mathrm{kg}$ \\
\hline 16 & Alachlor & AOAC $970.52 / E P A 525.5$ & Not detected & $0.01 \mathrm{mg} / \mathrm{kg}$ \\
\hline 17 & Butachlor & AOAC $970.52 / E P A 525.5$ & Not detected & $0.01 \mathrm{mg} / \mathrm{kg}$ \\
\hline 18 & Monochlorphos & AOAC $970.52 / E P A 525.5$ & Not detected & $0.01 \mathrm{mg} / \mathrm{kg}$ \\
\hline 19 & Phorate & AOAC $970.52 / E P A 525.5$ & Not detected & $0.01 \mathrm{mg} / \mathrm{kg}$ \\
\hline 20 & Mevinphos & AOAC $970.52 / E P A 525.5$ & Not detected & $0.01 \mathrm{mg} / \mathrm{kg}$ \\
\hline 21 & Dimethoate & AOAC $970.52 / \mathrm{EPA} 525.5$ & Not detected & $0.01 \mathrm{mg} / \mathrm{kg}$ \\
\hline 22 & Malathion & AOAC $970.52 / E P A 525.5$ & Not detected & $0.01 \mathrm{mg} / \mathrm{kg}$ \\
\hline 23 & Methyl-parathion & AOAC $970.52 / \mathrm{EPA} 525.5$ & Not detected & $0.01 \mathrm{mg} / \mathrm{kg}$ \\
\hline 24 & Chlorpyrifos & AOAC $970.52 / E P A 525.5$ & Not detected & $0.01 \mathrm{mg} / \mathrm{kg}$ \\
\hline 25 & Ethion & AOAC $970.52 / E P A 525.5$ & Not detected & $0.01 \mathrm{mg} / \mathrm{kg}$ \\
\hline 26 & Atrazine & AOAC $970.52 / E P A 525.5$ & Not detected & $0.01 \mathrm{mg} / \mathrm{kg}$ \\
\hline 27 & Simazine & AOAC $970.52 / E P A 525.5$ & Not detected & $0.01 \mathrm{mg} / \mathrm{kg}$ \\
\hline 28 & Diazinone & AOAC $970.52 / E P A 525.5$ & Not detected & $0.01 \mathrm{mg} / \mathrm{kg}$ \\
\hline 29 & Phosphamidon & AOAC970.52/EPA525.5 & Not detected & $0.01 \mathrm{mg} / \mathrm{kg}$ \\
\hline 30 & Fenitrothion & AOAC $970.52 / \mathrm{EPA} 525.5$ & Not detected & $0.01 \mathrm{mg} / \mathrm{kg}$ \\
\hline
\end{tabular}

Table 7: Determination of aflatoxin residues.

\begin{tabular}{|c|c|c|c|c|}
\hline $\begin{array}{l}\text { Sr. } \\
\text { No }\end{array}$ & $\begin{array}{c}\text { Test } \\
\text { parameter }\end{array}$ & Test method & Results & MDL \\
\hline 1 & AflatoxinB1 & AOAC 990.332 & $\begin{array}{c}\text { Not } \\
\text { detected }\end{array}$ & $1.0 \mu \mathrm{g} / \mathrm{kg}$ \\
\hline 2 & AflatoxinB2 & AOAC 990.33 & $\begin{array}{c}\text { Not } \\
\text { detected }\end{array}$ & $1.0 \mu \mathrm{g} / \mathrm{kg}$ \\
\hline 3 & AflatoxinG1 & AOAC 990.33 & $\begin{array}{c}\text { Not } \\
\text { detected }\end{array}$ & $1.0 \mu \mathrm{g} / \mathrm{kg}$ \\
\hline 4 & AflatoxinG2 & AOAC 990.33 & $\begin{array}{c}\text { Not } \\
\text { detected }\end{array}$ & $1.0 \mu \mathrm{g} / \mathrm{kg}$ \\
\hline
\end{tabular}

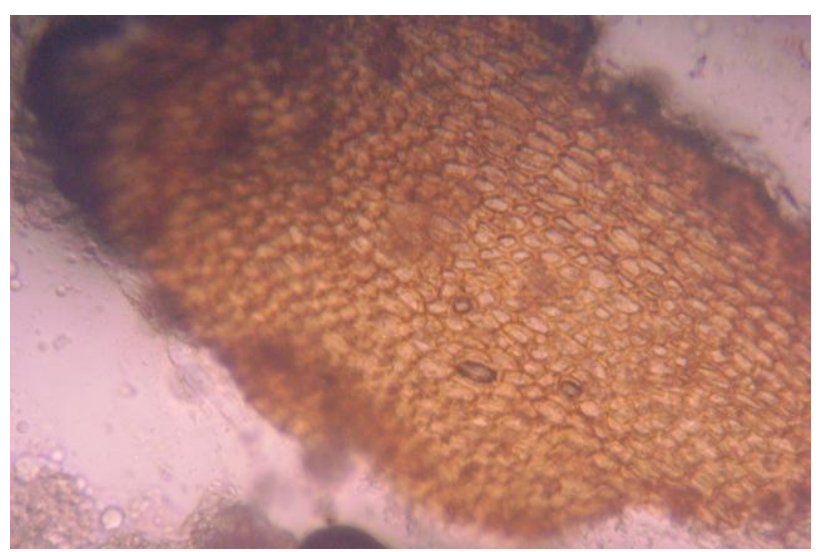

Figure 2: Cells of testa in surface view.

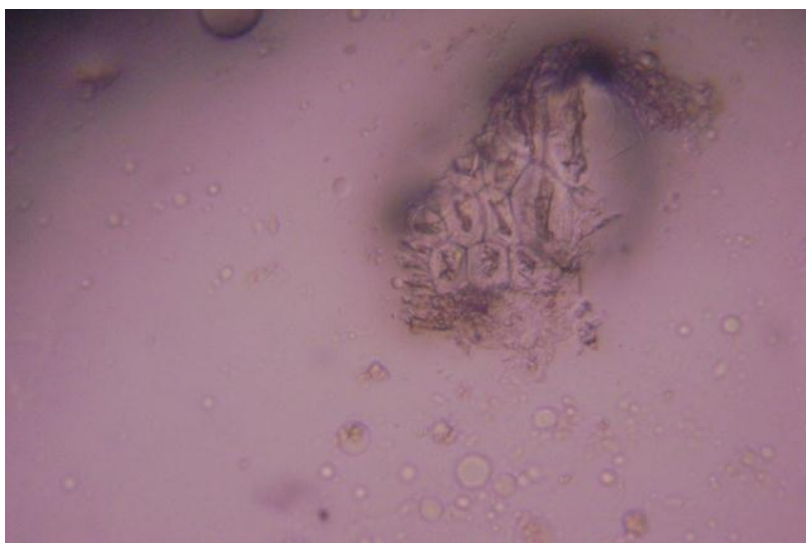

Figure 1: Cells of endosperm in surface view.

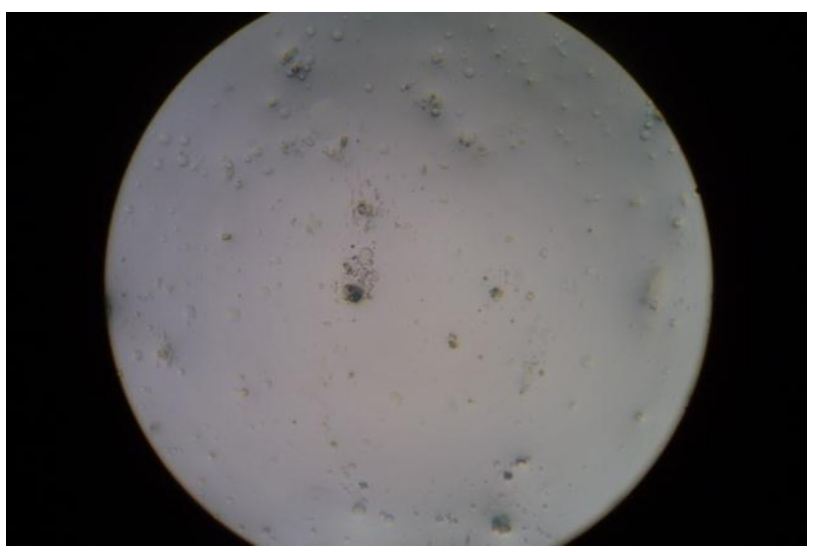

Figure 3: Starch granules. 


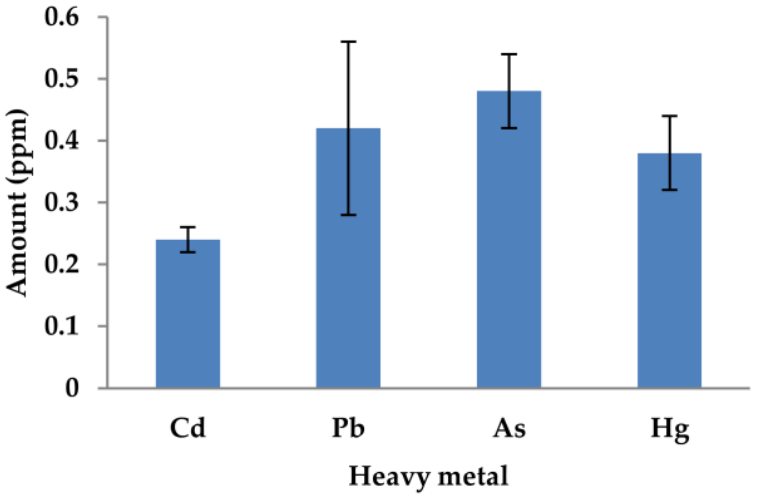

Figure 4: Heavy metal residue for Lepidium sativum.

extractive value and loss on drying, were also determined shown in (table 2). Fluorescence nature of the powder gardencress drug in different solvent extracts with different chemicals were analyze using longer light wavelength (366 nm) and shorter light wavelength $(254 \mathrm{~nm})$ were reported in (table 3$)$. Preliminary qualitative phytochemical screening showed that presence of alkaloids, carbohydrates, flavonoids and saponins. The presence or absence of particular types of phytoconstituents in the plant may be helpful in the development of analytical profile. The preliminary chemical tests of halon extracts were performed to detect the presence and absence of various phytoconstituents. The results of the performed studies are tabulated in table 4. Determination of heavy metals was carried out in the extracts of $L$. sativum on Atomic Absorption Spectrophotometer. The Cadmium was found to be highest in L. sativum sample $(0.24 \pm 0.05 \mathrm{mg} / \mathrm{kg})$ but it was below the permissible limit of $0.3 \mathrm{mg} / \mathrm{kg}$ as prescribed by WHO in all the samples. Lead ranged from $0.16 \pm 0.06 \mathrm{mg} / \mathrm{kg}$ to $0.43 \pm 0.05 \mathrm{mg} / \mathrm{kg}$ in all samples and was far below to the permissible limit of $10 \mathrm{mg} / \mathrm{kg}$ as prescribed by WHO. Mercury in all the samples was found to be below the permissible limit. Arsenic and mercury was found in all samples. Both metals were present within permissible limits of $0.5 \mathrm{ppm}$ and $1.0 \mathrm{ppm}$, respectively (table 5 and figure 4 ).

Determination of pesticide residue was carried out in extracts of L. sativum by standard methods as mention in AOAC guidelines. Total 30 pesticides were tested in all halon samples, none of the pesticides was found in halon extracts (table 6). Mycotoxins are secondary product of metabolites developed by fungus that develop in food products naturally. Toxigenic fungus may contaminate herbal products at different stages of production and processing, mainly due to the presence of humidity and temperature in favorable conditions. Many mycotoxins also have potential stability, which enables their persistence in products after the removal of the fungus by means of the commonly manufacturing and packaging processes.

The most common toxigenic fungi found in plants include species from the genus Aspergillus and Fusarium, mainly Aspergillus parasiticus Aspergillus flavus, and Fusarium verticillioides. Aspergillus fungi produce aflatoxins $G_{1}, G_{2}, B_{1}$ and $B_{2}$, which are considered to be involved in the etiology of human hepatic sarcoma. Aflatoxins $\mathrm{G}_{1}, \mathrm{G}_{2}$, $\mathrm{B}_{1}$ and $\mathrm{B}_{2}$, were determined in the extract of L. sativum. No aflatoxin was detected.

\section{CONCLUSION}

The generated data of this study will be used to establish its quality and purity and may be utilised to develop pharmacopoeial monograph of this plant. L. sativum L seeds have wide range of medicinal values. The outcome of this research work might prove beneficial in herbal industries for herbal industrialization, identification, purification and standardization of L. sativum L seeds extracts.

\section{REFERENCES}

Al-Yahya et al. (1994). Pharmacological and Safety evaluation studies on Garden cress (Lepidium sativum L.) seeds. Phytomedicine, Vol 1, Issue 2, Pages 155-159. [DOI]

Anonymous. (2002). Association of Official Analytical Chemists (AOAC) $17^{\text {th }}$ edition, methods AOAC 970.33 , methods AOAC 990.33 .

Anonymous. (2003). Ouality Standards of Indian Medicinal Plants. Vol- I, Indian Council of Medicinal Research, New Delhi. ISBN-0972-721

Chase et al. (1949). Fluorescence of powdered vegetable drugs with particular reference to development of a system of identification. J of American Pharma Asso, Vol 38 Issue 6, Pages 324- 331 [DOI]

Eddouks et al. (2005). Study of the hypoglycaemic activity of Lepidium sativum L. aqueous extract in normal and diabetic rats. Journal of Ethnopharmacology, Vol 97 Issue 2, Pages 391-395. [DOI]

Elisabetta.etal. (2007) Growth and protein profile changes in Lepidium sativum L. plantlets exposed to cadmium. Environmental and Experimental Botany, Vol 59 Issue 2, Pages 179-187. [DOI]

Gokavi et al., (2004). Chemical composition of garden cress (Lepidium sativum) seeds and its fractions and use of bran as a functional ingredient. Plant Food. Hum. Nutr, Vol 59, Issue 3,Pages 105-111. [DOI]

Harborne (1999). Phytochemical methods. A guide to modern technique of plant analysis. Plant Pathology, Vol 48, Issue 1, Pages 199. [DOI]

Herlich K. (1991) Official method of analysis of the Association of official analysis chemists AOAC. Analytica Chimica Acta Arlington USA, Vol 242, Pages 302. [DOI]

Julian, S, Pflugmacher, S. (2007). Antioxidative stress response of Lepidium sativum due to exposure to cyanobacterial secondary metabolites. Toxicon, Vol 50, Issue 1, Pages 85-93. [DOI]

Kokoshi et al. (1958). Fluorescence of powdered vegetable drugs under UV radiation. J American Pharma Asso, Vol 47, Issue 10, Pages 715-717. [DOI]

Koleva, I.I. et al. (2002). Screening of plant extracts for antioxidant activity: a comparative study on three testing methods. Phytochemical Analysis, Vol 13 Issue 1, Pages 8-17. [DOI]

Lee et al., (2004). Reactive oxygen species, aging and antioxidative neutraceuticals. Comp Rev Food Sci Food Safety, Vol 3, Issue 1, Page 21-33. [DOI]

Maghrani, et al. (2005) Antihypertensive effect of Lepidium sativum L. in spontaneously hypertensive rats. Journal of Ethnopharmacology, $\mathrm{Vol}$ 100, Issue1-2, Pages 193-197. [DOI]

Maier et al. (2002). A process for the preparation of dietary fibre from garden cress seeds. Indian Patent No.242/DEL.

Mathews et al. (1993). Some physicochemical characteristics of Lepidium sativum (haliv) seeds. Die Nahrung, Vol 37 Issue 1 Pages 69-71. [DOI]

McConnell et al. (2007). Physical characteristics of vegetable foodstuffs that could influence bowel function. J Sci Food Agric, Vol 25, Issue 12, Page 1457-1464. [DOI]

Mughal et al., (1999) A steryl ester from Lepidium sativum. Phytochemistry, Vol 50, Issue 8, Pages 1375-1377. [DOI]

Mukherjee (2002). Quality control of herbal drugs. Business Horizons pharmaceutical Publishers New Delhi. ISBN 81-900788-4-4.

Paolo Scartezzini, Ester Speroni et al., (2004) Review of some plants of Indian traditional medicine with antioxidant activity. Journal of Ethno pharmacology, Vol 71, Issue 1-2, Pages 23-43. [DOI]

Samson et al. (2001). Mycotoxins and phycotoxins in perspective at the turn of the millennium. Chemistry International - Newsmagazine for IUPAC Vol 24, Issue 1, Pages 23-23. [DOI]

Shoba, F.G., Thomas, M. (2001) Study of antidiarrhoeal activity of four medicinal plants in castor-oil induced diarrhea. Journal of Ethnopharmacology, Vol 76, Issue 1, Pages 73-76. [DOI]

Ulrich et al., (1998) Seven Imidazole Alkaloids from Lepidium sativum. Phytochemistry. Vol. 49, Issue 6, Pages 1791-1795. [DOI]

Welbourne, T. C. (1979) Ammonia production and glutamine incorporation into glutathione in the functioning rat kidney. Can J Biochem, Vol 57, Issue 3, Pages 233-237. [DOI]

Wright et al., (2007). Herbal medicines as diuretics: A review of the scientific evidence. Journal of Ethnopharmacology, Vol 114, Issue 1, Pages 1-31. [DOI] 